\title{
The significance of leisure property in property portfolios in Australia
}

Received (in revised form): 1 March 2007

\section{Graeme Newell}

is Professor of Property Investment at the University of Western Sydney. He has strong links to the property industry both in Australia and internationally via the Australian Property Institute and the RICS. His research interests include LPTs, property risk analysis and the role of property in investment portfolios.

\section{Hsu Wen Peng}

is research officer in the Property Research Group at the University of Western Sydney. His research interests include the role of emerging property sectors in investment portfolios.

\begin{abstract}
Recent years have seen an increased attention given to the property investment opportunities available from the leisure property sector. This paper will assess the significance of leisure property in property portfolios in Australia; particularly in listed property trusts (LPTs) and highlighting issues such as the current portfolio levels and the leading property funds in the leisure property sector. A leisure property LPT performance index is established and leisure property risk-adjusted performance analysis carried out over between 2000 and 2006, as well as the portfolio diversification benefits of the leisure property are assessed. Compared to the other LPT sectors, leisure property LPTs have shown an outstanding performance, as well as providing strong risk-adjusted returns and portfolio diversification benefits compared to the other LPT sectors and the major asset classes. The future implications for leisure property investment in the UK are also highlighted.
\end{abstract}

\section{Keywords:}

leisure property, LPTs, risk-adjusted performance, portfolio diversification

Journal of Retail and Leisure Property (2007) 6, 109-116. doi:10.1057/palgrave.rlp.5100051

Graeme Newell

School of Economics and Finance University of Western Sydney Locked Bag 1797,

Penrith South NSW 1797, Australia

Tel: + 61298524175

Fax: +61298524185

E-mail: g.newell@uws.edu.au

\section{INTRODUCTION}

Institutional investors in Australia have traditionally concentrated on low-risk core property portfolios of office, retail and industrial properties. Recent years, however, have seen significant capital inflows available for property, largely driven by the growth in pension fund assets, which accounted for over AU\$900bn in June 2006. ${ }^{1}$ These pension funds have 
also recently shown an increased appetite for property investment. This has seen significant growth in the listed property trust (LPT) sector, a shortage of quality local commercial properties, subsequent reduced yields and an increased exposure to international property investment opportunities. ${ }^{2,3}$

This mismatch between available funds and available core property assets in Australia has also seen institutional investors expand their focus beyond the traditional core property sectors to consider both higher risk value-added property and opportunistic property, and the property investment opportunities for enhanced returns available from the range of emerging property sectors. ${ }^{2,4}$ Among these emerging property sectors, such as healthcare, retirement and self-storage, leisure property has been a significant sector that has recently attracted the attention of institutional investors in Australia.

Only limited research has been conducted regarding leisure property. This has largely concentrated on valuation procedures, ${ }^{5}$ securitisation issues, ${ }^{6}$ impact of introduction of UK REITs, ${ }^{7}$ expanded focus of leisure property ${ }^{8}$ impact of new licensing legislation ${ }^{9}$ and current trends in leisure property. ${ }^{10}$ Importantly, leisure property has some different key features to the traditional property sectors for institutional investors to assess in formulating their property portfolio strategies, ${ }^{4}$ these include:

- operating business being linked with the property asset;

- difficulties predicting cashflows;

- lack of long-term investment performance series;

- small size of niche market;

- lack of institutional experience with leisure property; and

- need for revised fund mandates to invest in leisure property.

As such, the purpose of this paper is to rigorously assess the significance of leisure property in property portfolios in Australia; particularly, highlighting issues such as the current portfolio levels and the leading leisure property funds. A leisure property LPT performance index is established and leisure property risk-adjusted performance analysis carried out over 2000-2006, as well as the portfolio diversification benefits of leisure property assessed. The implications for leisure property investment in the UK are also assessed.

\section{LEISURE PROPERTY FUND PROFILE}

Table 1 presents the major leisure property funds in Australia in June 2006. Thirteen leisure property funds were identified, accounting for 281 properties valued at AU\$2.17bn (AU\$1 $=£ 0.405)$. The leisure sector is the largest emerging property market sector in Australia, ${ }^{4}$ with a diverse range of leisure property types including pubs, theme parks, marinas, bowling centres, theatres, restaurants, caravan parks, ski resorts, aquariums and tourist parks. Major institutional investors such as ING and Macquarie are actively involved in the leisure property sector, using both listed and unlisted property funds to obtain exposure to the leisure property sector. Many of these leisure property funds have only been established recently. 
Table I: Leisure property funds: June 2006

\begin{tabular}{|c|c|c|c|c|}
\hline Property fund & $\begin{array}{l}\text { Year } \\
\text { established }\end{array}$ & $\begin{array}{l}\text { Number of } \\
\text { properties }\end{array}$ & $\begin{array}{l}\text { Total } \\
\text { assets* }\end{array}$ & $\begin{array}{l}\text { Leisure property } \\
\text { sectors }\end{array}$ \\
\hline \multicolumn{5}{|l|}{ LPTs } \\
\hline Macquarie Leisure & 1998 & 58 & $\mathrm{AU} \$ 458 \mathrm{M}$ & $\begin{array}{l}\text { Theme park, marinas, } \\
\text { bowling alleys }\end{array}$ \\
\hline ING Entertainment Fund & 2004 & 24 & $A \cup \$ 262 M$ & Pubs \\
\hline ALE Property Group & 2003 & 106 & AU\$754M & Pubs \\
\hline Tourism and Leisure Trust & 1997 & 1 & $A \cup \$ 29 M$ & Hotel \\
\hline MFS Living and Leisure Group & 1999 & 7 & $A \cup \$ 373 M$ & Ski resort, aquariums \\
\hline MTM Entertainment Trust & 1998 & 1 & $A \cup \$ 2 M$ & Cinema \\
\hline \multicolumn{5}{|l|}{ Unlisted property funds } \\
\hline Grant Samuel Laundy Pub Fund & 2005 & 5 & AU\$70M & Pubs \\
\hline JF Tourist Park Fund & 2004 & 2 & AU\$29M & Tourist parks \\
\hline Aspen Parks Property Fund & 2004 & 13 & AU\$99M & $\begin{array}{l}\text { Caravan parks, holiday } \\
\text { parks }\end{array}$ \\
\hline Abacus Mariners Cove Trust & 2000 & 1 & AU\$7M & Restaurant/marina \\
\hline Westpac Family Restaurant Trust & 2002 & 35 & $A \cup \$ 52 M$ & Restaurants \\
\hline Westpac Family Restaurant Trust No. 2 & 2002 & 28 & $A \cup \$ 36 M$ & Restaurants \\
\hline Australian Golf Income Trust & 2006 & Open** & Open** & Golf resort \\
\hline
\end{tabular}

*Note AU $\$ I=Ł 0.405$ at June 2006

**Yet to acquire properties

Table 2: Asset class performance: June 2006

\begin{tabular}{lrrrr}
\hline Asset class & \multicolumn{5}{l}{ Average annual return (\%) } \\
\cline { 2 - 5 } & $\mathbf{I Y}$ & $\mathbf{3 Y}$ & $\mathbf{5 Y}$ & $\mathbf{1 0 Y}$ \\
\hline Direct property & $15.3(3)$ & $13.5(3)$ & $12.2(3)$ & $11.2(3)$ \\
LPTs & $18.1(2)$ & $17.9(2)$ & $16.2(1)$ & $14.8(1)$ \\
Shares & $24.2(1)$ & $23.8(1)$ & $12.4(2)$ & $12.8(2)$ \\
Bonds & $2.8(4)$ & $5.3(4)$ & $5.9(4)$ & $7.2(4)$ \\
\hline
\end{tabular}

Ranks of performance of asset classes per period are given in parentheses

Given the significant stature and performance of LPTs in recent years in Australia ${ }^{3,11}$ (see Table 2), the leisure property sector has made more substantial use of LPTs as the property investment vehicle, with Macquarie Leisure (AU\$458m), ALE Property Group (AU\$754m), MFS Living \& Leisure Group (AU\$373m) and ING Entertainment Fund (AU \$262m) being the most substantial LPT vehicles. For example, Macquarie Leisure has a diverse portfolio comprising the Dreamworld theme park, six marinas and over 50 bowling centres. Similarly, the ALE Property Group has a portfolio of 106 pubs (hotel assets of Fosters) leased on 25-year leases. Currently, the leisure property LPT sector is still a niche market, accounting for 1 per cent of the overall LPT market, but having increased from only 0.5 per cent in $2002 .{ }^{12}$

The unlisted leisure property funds (7) tended to be smaller with less diversified portfolios, comprising pubs, tourist facilities and restaurants. Several major institutional investors (eg Macquarie and Westpac) are utilising unlisted property funds to obtain leisure property exposure. A key factor in leisure funds investing in pubs has been the significant gaming facilities now in pubs in Australia that have further enhanced the revenue stream diversity from pub investments. 


\section{LEISURE PROPERTY PERFORMANCE ANALYSIS}

At this stage, any performance analysis of the leisure property sector needs to be based on the leisure property LPT market, as direct leisure property sector performance series are not available in Australia.

Table 3 presents the performance analysis for the various leisure property LPTs over the last five years as in June 2006. Consistent strong performance is seen by most of these leisure property LPTs; in many cases, significantly out-performing the overall LPT sector. In particular, Macquarie Leisure has delivered average annual returns consistently above 35 per cent over these one-, three- and five-year periods; in each case, generating returns at least approximately double that was seen by the overall LPT sector. Macquarie Leisure was also the best performed LPT over the three-year and five-year periods among the 32 LPTs included in the top 300 companies in the Australian stockmarket. ${ }^{12}$

To assess more fully the overall performance of leisure property LPTs, a leisure property LPT sector performance index was constructed by the authors. This quarterly total return performance index was constructed over the six-year period of Q2:2000-Q2:2006 using the six leisure property LPTs shown in Table 3. The resulting market capitalisationweighted performance index incorporated each of these leisure property LPTs as they were introduced over this six-year period.

Using this constructed leisure property LPT index, Table 4 presents the performance analysis of the leisure property LPT sector compared to the other LPT sectors over a one-, three- and five-year period as in June 2006. In each case, the leisure property LPT sector showed strong performance,

Table 3: Leisure property LPT performance analysis: June 2006

\begin{tabular}{llcl}
\hline \multirow{2}{*}{ Leisure property LPT } & \multicolumn{2}{c}{ Average annual return (\%) } \\
\cline { 2 - 4 } & IY & 3Y & 5Y \\
\hline Macquarie Leisure & 34.8 & 58.2 & 47.7 \\
ALE Property Group & 39.3 & $\mathrm{NA}$ & $\mathrm{NA}$ \\
ING Entertainment Fund & 13.4 & $\mathrm{NA}$ & $\mathrm{NA}$ \\
Tourism and Leisure Trust & 41.1 & 44.5 & $\mathrm{NA}$ \\
MFS Living and Leisure Group & 49.3 & 52.9 & $\mathrm{NA}$ \\
MTM Entertainment Trust & -0.4 & 6.5 & 20.1 \\
LPT Sector & 18.1 & 17.9 & 16.2 \\
\hline
\end{tabular}

Note: NA=not available; LPT does not have sufficient performance history over 3- or 5-year period

Table 4: LPT sector performance analysis: June 2006

\begin{tabular}{llll}
\hline LPT sector & \multicolumn{3}{l}{ Average annual return (\%) } \\
\cline { 2 - 4 } & IY & 3Y & 5Y \\
\hline Total & $18.09(4)$ & $17.90(4)$ & $16.18(4)$ \\
Office & $18.07(5)$ & $14.44(6)$ & $11.98(6)$ \\
Retail & $7.91(6)$ & $18.52(3)$ & $17.07(3)$ \\
Industrial & $40.03(1)$ & $30.21(2)$ & $25.48(2)$ \\
Diversified & $27.08(3)$ & $15.80(5)$ & $15.53(5)$ \\
Leisure & $34.06(2)$ & $54.14(1)$ & $45.21(1)$ \\
\hline
\end{tabular}

Ranks of performance of asset classes per period are given in parentheses 
being the best performed LPT sector on a three- and five-year basis, and being the second best performed LPT sector on a one-year basis.

To assess the performance of leisure property LPTs against the other major asset classes in Australia, Table 5 presents the risk-adjusted performance analysis over Q2:2000-Q2:2006 using performance series for the other asset classes provided by IPD/PCA. ${ }^{13}$ Leisure property LPTs gave significantly higher average annual returns (28.83 per cent) over 2000-2006 than any other asset classes, although the annual risk for the leisure property LPTs (23.36 per cent) was also significantly higher than the other asset classes, including the stockmarket (11.94 per cent). This higher risk profile for the leisure property sector is consistent with property industry expectations. ${ }^{14}$ On a risk-adjusted basis (using the Sharpe index), the leisure property sector was ranked third, behind direct property (\#1) and the overall LPT sector (\#2).

To put this risk profile for leisure property LPTs into a more recent context, however, Figure 1 clearly shows the leisure property LPT risk profile decreasing significantly in more recent years. This is in marked contrast to the increased LPT sector risk profile in recent years (see Figure 2), reflecting the recent higher risk LPT activities of significant international property investment, higher levels of debt, stapling and engaging in property development activities. ${ }^{3}$

Table 5: Leisure property performance analysis: Q2:2000-Q2:2006

\begin{tabular}{llcc}
\hline Asset class & $\begin{array}{l}\text { Average annual } \\
\text { return (\%) }\end{array}$ & Annual risk (\%) & Sharpe index \\
\hline LPTs & 16.17 & 7.03 & $1.54(2)$ \\
Leisure property LPTs & 28.83 & 23.36 & $1.01(3)$ \\
Direct property & 12.06 & 1.65 & $4.09(1)$ \\
Shares & 12.10 & 11.94 & $0.57(4)$ \\
Bonds & 6.17 & 3.70 & $0.22(5)$ \\
\hline
\end{tabular}

Ranks of performance of asset classes per period are given in parentheses

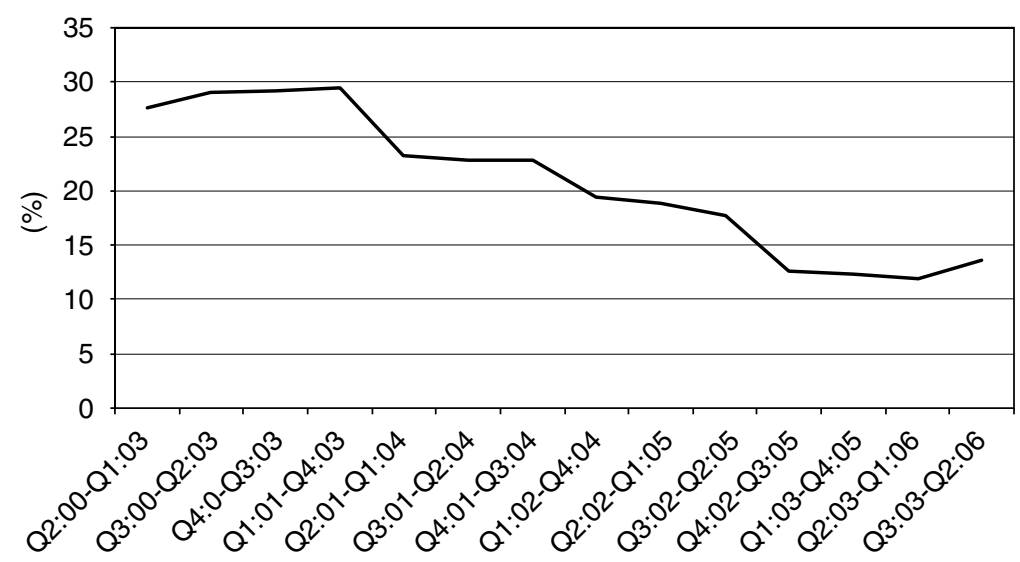

Figure I: 3 Year rolling risk profile for leisure property LPTs 


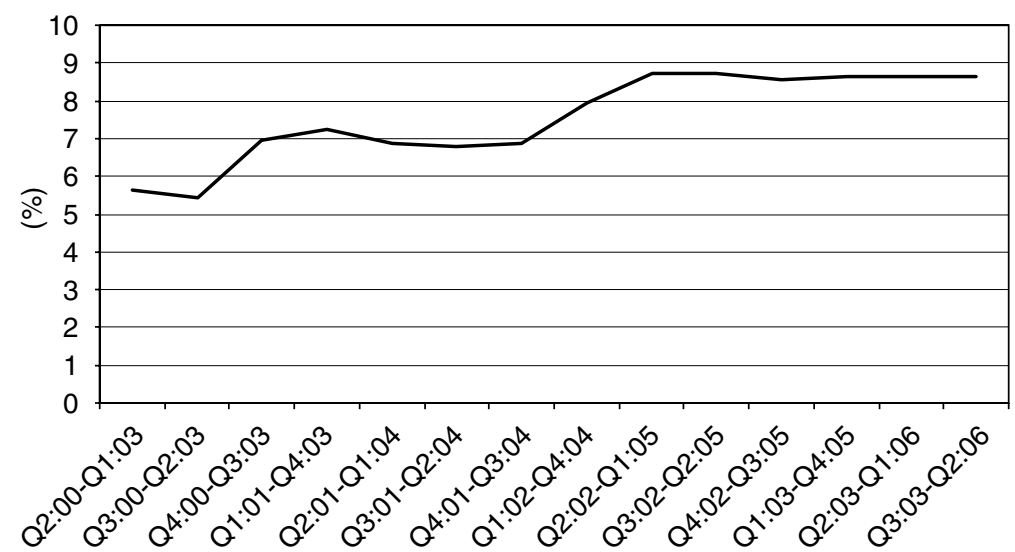

Figure 2: Rolling risk profile for LPT sector

Table 6: Inter-asset correlation matrix

\begin{tabular}{lllll}
\hline & LPTs & $\begin{array}{l}\text { Leisure property } \\
\text { LPTs }\end{array}$ & Direct property & Shares \\
\hline Leisure property LPTs & $0.43^{*}$ & & & \\
$\begin{array}{l}\text { Direct property } \\
\text { Shares }\end{array}$ & 0.33 & 0.16 & & \\
Bonds & 0.24 & $0.64^{*}$ & 0.24 & -0.48 \\
\hline
\end{tabular}

*Significant correlation $(p<5 \%)$

\section{LEISURE PROPERTY DIVERSIFICATION BENEFITS}

To assess the portfolio diversification benefits of the leisure property LPTs, Table 6 presents the inter-asset correlation matrix for the leisure property LPT sector and the major asset classes over Q2:2000-Q2:2006. While leisure property LPTs were correlated with the overall LPT sector $(r=0.43)$, this correlation was significantly less than the other LPT subsectors with the overall LPT sector $(r=0.69$ to $r=0.83)$. With the leisure property LPTs having correlations with the other LPT subsectors ranging from $r=0.29$ (diversified LPTs) to $r=0.48$ (office LPTs), this reflects significant portfolio diversification benefits by leisure property LPTs in an LPT portfolio. The nonsignificant correlation of leisure property LPTs and retail LPTs $(r=0.33)$ does not support the traditional European view that leisure property is a subsector of retail property. ${ }^{14}$

Leisure property LPTs were also significantly correlated with the stockmarket $(r=0.64)$; this being in contrast to the other LPT subsectors that showed less alignment with the stockmarket $(r=0.10$ to $r=0.47)$. Leisure property LPTs were not correlated with direct property $(r=0.16)$, with the overall LPT sector showing a stronger alignment with direct property $(r=0.33)$. Overall, this reinforces the view that leisure property LPTs provide more diversification benefits in an LPT portfolio than the other LPT subsectors, but its performance is also aligned more strongly with the stockmarket than the other LPT subsectors. The alignment of 


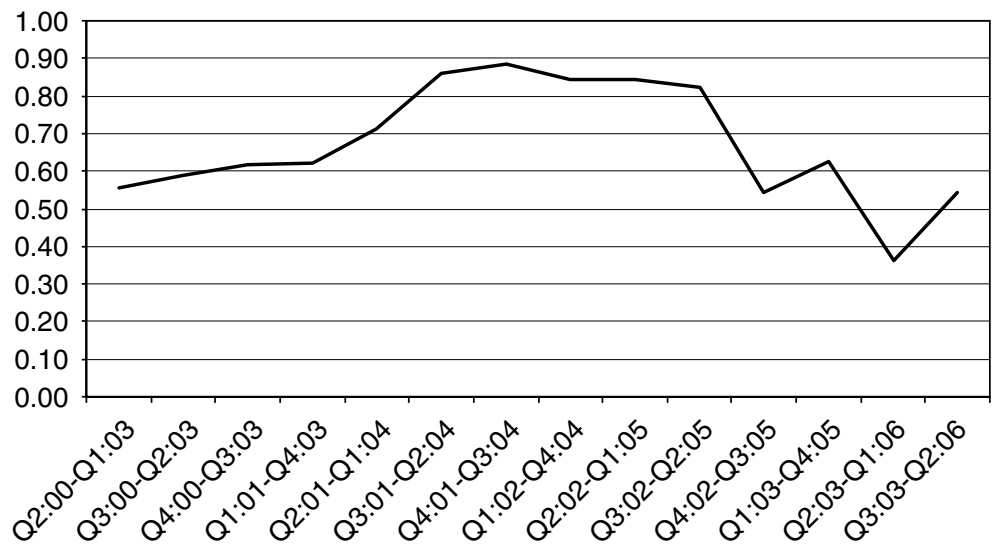

Figure 3: Rolling correlation profile for leisure property LPTs

leisure property LPTs and the stockmarket, however, has reduced significantly in more recent years (Figure 3 ).

\section{STRATEGIC IMPLICATIONS}

While past performance is no guarantee of future performance, the above analyses have confirmed the stature, performance and portfolio diversification benefits of leisure property via leisure property LPTs; enforcing the industry view of leisure property providing enhanced yields and diversification benefits. ${ }^{14}$

A key ongoing strategic issue, however, regarding leisure property in Australia is whether this strong performance can be sustained. While the leisure property sector is seen as a niche market, comes off a low base, and property funds have been able to identify quality leisure property assets and strategic alliances to manage the business risk component in this sector, the ability to continue this momentum will place considerable focus on the ongoing property asset selection and leisure property fund manager expertise.

While risk factors such as increasing interest rates and potential reduced disposable income are the key factors for the leisure sector, ongoing strong economic growth is expected in Australia, with the leisure sector typically more resilient in a downturn than the retail or tourism sectors. ${ }^{14}$ Increased institutional investor confidence and experience in the leisure sector is also expected to be a key factor in the ongoing development and maturity of the leisure property sector. Further, refining the business model for the operating business connected to the leisure property will also assist the sophistication of the leisure property sector.

\section{IMPLICATIONS FOR UK LEISURE PROPERTY}

While leisure property has not figured prominently in the UK institutional portfolios, there has been an increased recent interest in the leisure property sector. Excellent examples include the Capital \& Regional $\mathrm{X}$-Leisure Fund, established in 2003 with total assets of $£ 769 \mathrm{~m}$ including the 02 Centre in London, and the Legal \& General Leisure Fund, 
established in 2003 with total assets of $£ 270 \mathrm{~m}$ including the Barbican Leisure Park in Plymouth. ${ }^{14}$ This has been further enhanced by the strong performance of leisure property in the UK, with total returns of 12.0 per cent p.a. for the ten-year period to 2005, with an income component of 6.8 per cent p.a. based on the IPD index leisure property portfolio. ${ }^{14}$

A major catalyst to the exposure of the traditional UK property fund managers into the leisure property sector is expected to be the development of REITs in the UK in 2007, particularly with hotels now able to be included in the revised UK REIT structures. ${ }^{7}$ The liquidity provided by REITs in accessing quality property investment opportunities and the continued significant capital inflows into property are expected to further enhance the potential benefits of establishing leisure property funds.

The evidence provided in this paper concerning the significant stature and the performance of leisure property in Australia in suitably structured property investment vehicles such as LPTs further enhances the level of information available at an international level regarding the strategic property investment issues concerning the role and contribution of leisure property in portfolios.

\section{References}

1. Australian Prudential Regulatory Authority (2006). Statistics: Quarterly Superannuation Performance, APRA, Canberra, June 2006.

2. Blundell, L. (2005). Time to step outside the comfort zone. Property Australia. 20(1), 18-20.

3. Newell, G. (2006). The changing risk profile of listed property trusts. Australian Property Journal. 39, 172-180.

4. Newell, G. \& Peng, H.W. (2006). The significance of emerging property sectors in property portfolios. Pacific Rim Property Research Journal. 12, 178-198.

5. Sayce, S. (1996). Leisure property: A question of profit? Journal of Property Finance. 6, 7-27.

6. Cox, M. (2003). Pub securitisation: What next? Journal of Retail \& Leisure Property. 3, 130-136.

7. Nichols, M. \& Boutell, M. (2005). The introduction of REITs and their impact on the leisure sector. Journal of Retail \& Leisure Property. 4, 295-300.

8. Ravenscroft, N. \& Gilchrist, P. (2005). Delimiting leisure and culture: Towards a new definition of leisure property. Journal of Retail \& Leisure Property. 4, 313-323.

9. Owens, S. (2006). The impact of the new Licensing Act together with a difficult trading environment and other new legislation on capital and rental values of UK nightclubs. Journal of Retail \& Leisure Property. 5, 341-345.

10. Frost, C. (2003). Current trends in the UK property market for pubs, bars and restaurants. Journal of Retail \& Leisure Property. 3, 50-55.

11. Newell, G. (2005). The changing dynamics of Australian commercial property. Australian Property Journal. 38, 553-558.

12. UBS (2006). UBS Indices, UBS, Sydney, June 2006.

13. IPD/PCA (2006). Investment Performance Index, IPD/PCA, Melbourne, June 2006.

14. Strongin-Dodds, L. (2006). Wishing on a megastar. IPE Real Estate, (December), 42-43. 